\title{
Fermentation of Cellulose with a Mixed Microbial Rumen Culture with and without Methanogenesis
}

\author{
Birgitte Kiaer Ahring $^{1^{*}}$, Nanditha Murali ${ }^{2}$ and Keerthi Srinivas ${ }^{1}$ \\ ${ }^{1}$ Bioproducts Sciences and Engineering Laboratory, Washington State University, Tri-Cities, Richland, WA -99354, USA
}

${ }^{2}$ Gene and Linda Voiland School of Chemical Engineering and Bioengineering and Biological Systems Engineering, Washington State University, Pullman, WA-99163, USA

"Corresponding author: Birgitte Kiaer Ahring, Bioproducts Sciences and Engineering Laboratory, Washington State University, Tri-cities 2710 Crimson Way Richland, WA 99354, USA, Tel: +01-(509)-372-7682; Fax: 01-(509)-372-7690; E-mail: bka@wsu.edu

Received date: May 26, 2018; Accepted date: June 06, 2018; Published date: June 14, 2018

Copyright: (c) 2018 Ahring BK, et al. This is an open-access article distributed under the terms of the Creative Commons Attribution License, which permits unrestricted use, distribution, and reproduction in any medium, provided the original author and source are credited.

\begin{abstract}
Ruminal fermentation has been well studied and includes cellulolytic microorganisms to hydrolyze cellulose to monomers, acidogenic microbes including cellulolytic microorganism to convert the monomers to volatile fatty acids (VFA), hydrogen and carbon dioxide and methanogens to convert the acetic acid, hydrogen and carbon dioxide to methane. Notably, methane production in ruminants causes energy loss for the animal and emitted methane contributes significantly to greenhouse gases in the atmosphere. The present study focuses on selectively inhibiting of the methanogens using 2-bromoethanesulfonate (BES) and its effect on ruminal fermentation in an anaerobic rumen bioreactor model system. It was found that BES inhibited methane production $(99.7 \%)$ and that addition of BES decreased the total VFA productivity from $3 \mathrm{~g} / \mathrm{L} /$ day to $1.3 \mathrm{~g} / \mathrm{L} /$ day. Our study also found that addition of BES not only inhibited the methanogens, but also had an impact on the non-methanogenic bacteria as well, resulting in a decrease in the acetic acid productivity from $1.8 \mathrm{~g} / \mathrm{L} / \mathrm{day}$, in a reactor without BES to $0.8 \mathrm{~g} / \mathrm{L} /$ day in reactor with BES added. Endoglucanase assay revealed that addition of BES further inhibits cellulolytic microbes, resulting in a decrease in endoglucanase concentration in the reactor supplemented with BES. A notable increase in hydrogen partial pressure was seen in the reactor with BES (from $1.7 \%$ to $29.8 \%$ ).
\end{abstract}

Keywords: Rumen; Methanogenesis; BES; Volatile fatty acids; Hydrogen; Carbon dioxide

\section{Introduction}

Cellulose, the most abundantly available polymer, found in both plant and animal cells as a structural material, is a branched polymer with $\beta$-D-glycosidic linkages [1]. Avicel is commercially-available microcrystalline cellulose produced from acid hydrolysis of amorphous cellulose to remove the fibrous hinges [2]. One of the key players in cellulosic degradation is the cellulolytic microorganisms [3], which can biologically convert cellulosic materials to volatile fatty acids (VFA) and gases such as hydrogen and carbon dioxide [4]. The different cellulolytic microorganisms, those that are naturally occurring in environment, such as the rumen has shown to be markedly more efficient in degrading cellulose to produce VFAs $[4,5]$. In addition to its superior cellulose degrading capabilities, studies have indicated that the rumen is also a rich source of different enzymes with different activities which will eliminate the need for separate enzymatic hydrolysis as often found in bio refineries [6]. Furthermore, fermentation using a mixed microbial rumen consortia, being nonsterile, can further significantly decrease process costs $[6,7]$.

Rumen microorganisms comprises of three groups of bacteria: fermentative bacteria that degrade cellulose anaerobically to produce monosaccharides; acidogenic and acetogenic bacteria that convert these monosaccharides to volatile fatty acids (VFA), and methanogenic Archae, which further hydrogen and carbon dioxide [8]. The fermentative bacteria hydrolyze complex compounds like polysaccharides, proteins and lipids into simpler compounds like monosaccharides, amino acids and fatty acids [9]. The cellulose, in particular, is converted to glucose by the action of cellulolytic bacteria through excretion of cellulase enzymes. Enzyme activities including, cellulases, hemicellulases, xylanases, etc. [10] have been confirmed in the rumen and ruminal cellulase activity is principally located on the bacterial cell surface [11]. The acidogenic and actogenic bacteria utilize the monosaccharides from the first hydrolysis step to produce acetic, propionic, butyric acids, hydrogen $\left(\mathrm{H}_{2}\right)$ and carbon dioxide $\left(\mathrm{CO}_{2}\right)$. The VFA including acetic acid, propionic acid and butyric acids are absorbed by the intestinal epithelia in the rumen and are the main source of energy for the animal [12].

Ruminant gut consists of almost $25 \%$ of Firmicutes, including Ruminococcus, Butyrivibrio, Eubacterium and Pseudobutyrivibrio species, which are responsible for cellulose hydrolysis in the rumen [13]. Interestingly, human gut microbiota has been characterized and it was found that gut of healthy adults consisted of Firmicutes and Bacteroidetes with significant amounts of Actinobacteria and Proteobacteria [14]. Additionally, the ruminant gut also contains $60 \%$ Bacteriodes including Bacteroidales and Prevotella, which degrades hemicellulose and pectin [15]. Hess et al., 2011 [16] found that rumen fluid consisted of $63 \% \beta-1,4$-endoglucanases, $86 \% \beta$-glucosidases and $87 \%$ cellobiohydrolases and recent studies have indicated that Bacteriodes and Bacteriodales are predominantly producers of $\beta$ glucanases and xylanases [17]. In addition to cellulolytic bacteria, ruminant gut also consists of acidogenic bacteria including Acetitomaculum, Propionibacterium, Peptostreptococcus, and Chlostridium, which convert the 'sugars' to volatile fatty acids (VFAs) and methanogens including mainly Methanobacter, Methanobrevibacter and Methanococcus, which convert formic acid, 
hydrogen and carbon dioxide to methane [18]. In some instances members of the genus Methanosarcina has further been identified [19].

Methanogenesis is an energetically-favorable final step in ruminants (Figure 1) and is vital in the rumen for continuous removal of hydrogen, production of ATP [20], which results in a stable rumen microbiome. However, methanogensis in the rumen results in almost $10-15 \%$ energy loss inside the animal as methane just leaves the system and ends in the atmosphere without any benefits for the animal in the form of meat. Methane emissions significantly contribute to global warming issues and methane emissions from cattle in the United States alone contribute to $21 \%$ of the global greenhouse gases [21]. Hence, extensive studies have been done on inhibiting methanogenesis during rumen fermentation. As methanogenesis functions as an important process for keeping stability of the system, increasing the $\mathrm{H}_{2}$ concentration can potentially have negative effect for the overall rumen fermentation.

$$
\begin{gathered}
4 \mathrm{H}_{2}+2 \mathrm{CO}_{2} \rightarrow \mathrm{CH}_{3} \mathrm{COOH}+2 \mathrm{H}_{2} \mathrm{O}\left(\Delta G^{o^{\prime}}=-104.6 \mathrm{KJ}\right) \\
4 \mathrm{H}_{2}+\mathrm{CO}_{2} \rightarrow \mathrm{CH}_{4}+2 \mathrm{H}_{2} \mathrm{O}\left(\Delta G^{o^{\prime}}=-135.6 \mathrm{KJ}\right)
\end{gathered}
$$

Figure 1: Thermodynamic differences between methanogenesis and acetogenesis showing that methanogenesis is energetically more favorable (McAllister \& Newbold, 2008); $\Delta$ Go' refers to the free energy of formation.

Studies have shown that inhibition of methanogenesis shifts the ruminal fermentation towards propionic acid and an increased butyric acid production [22] or acetogenesis [23]. Studies have also shown that mitigation of methane emissions can be done via chemical inhibitors, like ionophores or organic acids, or methane analogs like 2bromoethanesulfonate (BES). Although chemical inhibitors have been proven successful, this study focuses on inhibition with BES since it specifically inhibits methanogenesis and has been found to be effective in eliminating methane production or reducing it significantly [24]. BES is a Coenzyme $\mathrm{M}$ analog, which competitively inhibits the methyl transfer reaction during methanogenesis [25]. Many studies have reported that addition of BES to inhibit methanogenesis is effective in increasing biohydrogen production in microbial fuel cells [26,27]. Another study on rice soil with mixed microbes found that hydrogen accumulation happened within 7 days and the highest hydrogen accumulation happened at day 25 after inhibition of methanogenesis with BES [28]. Besides methanogens, acetogens producing acetic acid from hydrogen and carbon dioxide could potentially take place of the methanogens in the rumen, which would produce more value for the animals. As can be seen from the stoichiometrics of acetate production, this process is less energetic favorable compared to methanogenesis, and this difference has been regarded as the reason why acetogens have not occupied this space in the rumen [20]. Redirection of methanogenesis towards hydrogen production could further have technical interest as hydrogen is a potential interesting fuel with application in microbial fuel cells technology.

The focus of this paper is to study the effects of selectively inhibition of methanogenesis in a rumen-based bioreactor operating with cellulose as sole substrate and energy source. The bioreactor was inoculated with fresh cow rumen fluid and BES was added to selectively inhibit the methanogenic archea. The effect on the fermentation products including headspace gases were monitored along with cellulase enzyme activity in the bioreactor.

\section{Materials and Methods}

\section{Inoculum}

Fresh rumen fluid was collected from a slaughterhouse facility in Richland WA [29]. The rumen fluid was transported to the lab in tightly-sealed bottles and was degassed under $80 / 20 \%$ w/w $\mathrm{N}_{2}-\mathrm{CO}_{2}$ mixture and stored at $-20^{\circ} \mathrm{C}$ in anaerobic jars until further use. $10 \%$ rumen fluid was used as inoculum for all the experiments.

\section{Chemicals}

Sodium hydroxide $(5 \mathrm{~N})$, sulfuric acid $(4 \mathrm{mM})$, yeast extract, sodium 2-bromoethanesulfonate, cellulase enzyme from Trichoderma reesei and Avicel Ph-101 were obtained from Sigma Aldrich, (St. Louis, MO, USA). Oxarc Inc. (Pasco, WA, USA) provided the nitrogen carbon dioxide gas mix. Azo-CMC substrate for the cellulase assay was obtained from Megazyme (Bray, County Wicklow, IR).

\section{Fermentation}

\section{VFA fermentation at different $\mathrm{pH}$}

Batch experiments were conducted at different $\mathrm{pH}$, including $\mathrm{pH}$ 5.5, $\mathrm{pH} 6.0, \mathrm{pH} 6.5$ and $\mathrm{pH} 7.0$, all at $37^{\circ} \mathrm{C}$. This was done to evaluate the effect of $\mathrm{pH}$ on the fermentation products produced. Avicel $\mathrm{Ph}-101$ $(2.5 \%)$ was used as substrate in all the experiments. The fermentation media consisted of $2.5 \%$ avicel and $0.1 \%$ of yeast extract. The hydraulic retention time (HRT) for the fermentations was 6 days and the fermentations were carried out for 24 days (4 HRT). Daily gas analysis was done to measure headspace gases and High Performance Liquid Chromatography (HPLC) was done to analyze VFA production.

\section{Effect of BES on VFA fermentation}

Two 3L Applikon ${ }^{\circledR}$ ez Control Autoclavable bioreactor (Applikon Biotechnology B.V, Netherlands) were set up using $2.5 \%$ avicel and $0.1 \%$ yeast extract. Initially, $810 \mathrm{~mL}$ of fermentation medium was added to both the reactors and both were autoclaved at $121^{\circ} \mathrm{C}$ for 20 $\min$. Both reactors were inoculated with $10 \%$ fresh rumen fluid while being gassed under $80 \%$ nitrogen: $20 \%$ carbon dioxide gas mixture. To one reactor, sterile $10 \mathrm{mM}$ Sodium 2-Bromoethanesulfonate was added anaerobically defined as day 1 and again on day 15 to selectively inhibit potential methanogens still present in the reactor. Sodium hydroxide (5 $\mathrm{N}$ ) was used to initially adjust the $\mathrm{pH}$ to 6.5 and $5 \mathrm{~N}$ sodium hydroxide was used to maintain the $\mathrm{pH}$ at 6.5 throughout the fermentation. The hydraulic retention time was 6 days and the fermentation was done for 30 days (5 HRT). Daily analyses including gas analysis and VFA measurement was done to assess the stability of the fermentation.

\section{Analysis}

\section{Headspace gas Analysis}

Gas analyses of headspace gases was done using the Universal Gas Analyzer (UGA Series, Stanford Research Systems, Sunnyvale, CA). The gas measurements were in percentage of the headspace. 
Page 3 of 7

\section{HPLC analysis for VFA production}

The fermentation effluent was analyzed daily for VFA concentration using UltiMate 3000 HPLC system (Dionex, Sunnyvale, CA) with an Aminex $87 \mathrm{H}$ Column $250 \times 4.6 \mathrm{~mm}$ (Bio - Rad, Hercules, CA) at $60^{\circ} \mathrm{C}$ and a Shodex RI-101 refractive index detector. The effluent $(2$ $\mathrm{mL}$ ) was centrifuged at $10,000 \mathrm{rpm}$ for $10 \mathrm{~min}$ and the supernatant was filtered through a 0.2 micron filter and diluted 4 times with $4 \mathrm{mM}$ sulfuric acid in water. Sulfuric acid $(4 \mathrm{mM})$, flowing at a constant flow rate of $0.6 \mathrm{~mL} / \mathrm{min}$, was used as the eluent. The analysis time for the fermentation samples was $68 \mathrm{~min}$.

\section{Calculation}

Acetic, Propionic, butyric acids were the major acids produced during the fermentations. The total VFA was calculated in acetic acid equivalents in calculations similar to our previously reported study [29]. The equation (Figure 2) is as follows:

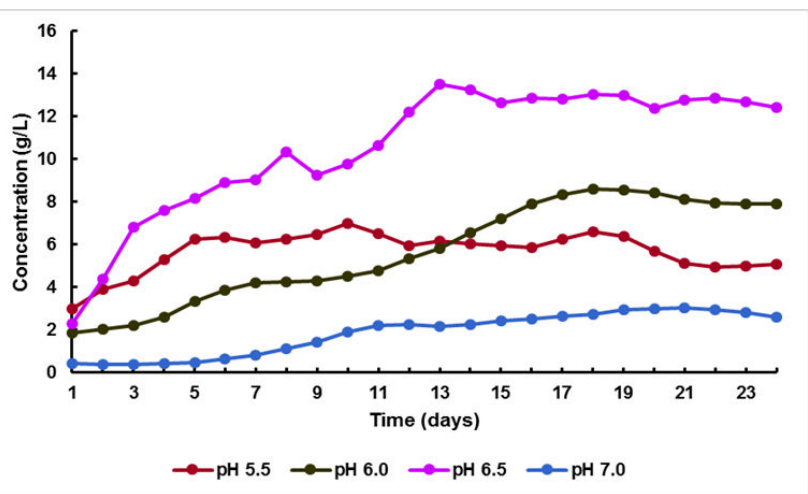

Figure 2: Total VFA concentrations at different $\mathrm{pH}$ values. VFA productions were tested at different $\mathrm{pH}$ and it was found that $\mathrm{pH}$ 6.5 worked optimally for production of VFA by the rumen fermentation. VFA production was decreased at a $\mathrm{pH}$ below or above 6.5 .

\section{Azo-Carboxymethyl cellulase assay}

Supplier instructions were followed to measure the endo-1, 4- $\beta$ Glucanase activity using the Azo-CMC substrate (Megazyme, Ireland). Briefly, a partially-depolymerized and dyed Azo substrate is prepared by dissolving the $2 \mathrm{~g}$ of the Azo-CMC in boiling water and adding sodium acetate buffer at $\mathrm{pH} 4.5$ to it. The fermentation effluent $(0.5$ $\mathrm{mL})$ is then added to the substrate $(0.5 \mathrm{~mL})$, both pre-equilibrated at $40^{\circ} \mathrm{C}$. This reaction was incubated for exactly $10 \mathrm{~min}$ in a vortex mixer and the reaction is terminated by adding $2.5 \mathrm{~mL}$ of precipitant solution (containing sodium acetate trihydrate and zinc acetate). After equilibrating at room temperature for $10 \mathrm{~min}$, the solution was centrifuged at $1000 \mathrm{gm}$ for $10 \mathrm{~min}$ and absorbance of the supernatant is measured at $590 \mathrm{~nm}$. The enzyme activity was determined from standard calibration curve made using the pure Azo substrate.

\section{Results and Discussion}

\section{The effect of $\mathrm{pH}$ on VFA fermentation}

Although studies have shown that $\mathrm{pH}$ between 5.0 and 6.0 is ideal for the production of acetic and propionic acids [30], our study found that at $\mathrm{pH} 5.5$, acetic acid was the dominant VFA with a concentration of $2.5 \mathrm{~g} / \mathrm{L}$ followed by propionic acid $(1.5 \mathrm{~g} / \mathrm{L})$ and butyric acid $(1 \mathrm{~g} / \mathrm{L})$. However, when the $\mathrm{pH}$ was increased to 6.0 , the fermentation shifted slightly towards more VFA resulting in more acetic acid $(3.5 \mathrm{~g} / \mathrm{L})$ and propionic acid $(3 \mathrm{~g} / \mathrm{L})$ with only minor amounts of butyric acid. These results were in accordance to previous studies that have found that between $\mathrm{pH} 6.0$ and $\mathrm{pH} 7.0$, acetic acid was the predominant VFA produced [31].

Upon further testing it was found that $\mathrm{pH} 7.0$ favored methanogenesis, as evident by the low concentrations of VFA (total VFA of $2 \mathrm{~g} / \mathrm{L}$ ) with $55 \%(\mathrm{w} / \mathrm{w}) \mathrm{CH}_{4}$ and $31 \%(\mathrm{w} / \mathrm{w}) \mathrm{CO}_{2}$ in the headspace (Table 1). It is observed that acetic acid production in anaerobic leach bed bioreactors was decreased at a lower $\mathrm{pH}$ (around 5) while more neutral $\mathrm{pH}$ would lead to higher concentrations [32]. These results are consistent with that obtained in this study. As can be seen from Figure 3, the total VFA production increased with an increase in $\mathrm{pH}$ between 5.5 and 6.5 with 6.5 showing the highest amount of VFAs (13 g/L acetic acid equivalents). This value is remarkably higher than that obtained at $\mathrm{pH} 6.0(8 \mathrm{~g} / \mathrm{L}$ acetic acid equivalents) and was predominantly made up of acetic and propionic. The inhibition of VFA production at $\mathrm{pH} 5.5$ can be seen in Figure 3 which is similar to the results observed by Cysneiros D, et al. [32].

Recent research [33] that showed similar trends on the acetic acid productivity as a function of $\mathrm{pH}$ as that found in this study, also found that Enterococcus were the dominant organism at $\mathrm{pH} 6.0$, while Enterobacter dominated at $\mathrm{pH}$ 6.5. Both bacteria are known to produce $\mathrm{H}_{2}$ besides other fermentation products from cellulose. A shift in microbial population towards Bacteroides, another cellulose degrader, was seen at $\mathrm{pH} 5.5$, and a shift towards increase importance of methanogenic archea was seen at $\mathrm{pH}$ above 7 [33]. Another study investigated the degradation of cellulose by rumen microbes at different $\mathrm{pH}$ and found that cellulose degradation also increased with an increase in $\mathrm{pH}$ [4]. This could be connected to an increase in the VFA production and will be discussed in greater detail in the following sections.

\begin{tabular}{|l|l|l|l|l|}
\hline Reactor & $\begin{array}{l}\text { Hydrogen } \\
\text { Concentratio } \\
\mathbf{n}(\%)\end{array}$ & $\begin{array}{l}\text { Carbon } \\
\text { dioxide } \\
\text { concentratio } \\
\mathbf{n}(\%)\end{array}$ & $\begin{array}{l}\text { Methane } \\
\text { Concentratio } \\
\mathbf{n}(\%)\end{array}$ & $\begin{array}{l}\text { Total VFA } \\
\text { Concentratio } \\
\mathbf{n}(\mathbf{g} / \mathrm{L})\end{array}$ \\
\hline At pH 5.5 & $1.9 \%$ & $27.8 \%$ & $11.9 \%$ & $5.6 \mathrm{~g} / \mathrm{L}$ \\
\hline At pH 6.0 & $1.1 \%$ & $26.1 \%$ & $11.8 \%$ & $8.1 \mathrm{~g} / \mathrm{L}$ \\
\hline $\begin{array}{l}\text { At pH 6.5 With } \\
\text { Methanogenes } \\
\text { is }\end{array}$ & $1.7 \%$ & $31.8 \%$ & $45.9 \%$ & $13.3 \mathrm{~g} / \mathrm{L}$ \\
\hline $\begin{array}{l}\text { At pH } 6.5 \\
\text { Without } \\
\text { Methanogenes } \\
\text { is }\end{array}$ & $29.8 \%$ & $29.2 \%$ & $0.1 \%$ & $8.3 \mathrm{~g} / \mathrm{L}$ \\
\hline At pH 7.0 & $0.8 \%$ & $31 \%$ & $54.8 \%$ & $1.9 \mathrm{~g} / \mathrm{L}$ \\
\hline
\end{tabular}

Table 1: Gas concentrations and VFA production at different pH's in the bioreactor. 
Citation: Ahring BK, Murali N, Srinivas K (2018) Fermentation of Cellulose with a Mixed Microbial Rumen Culture with and without

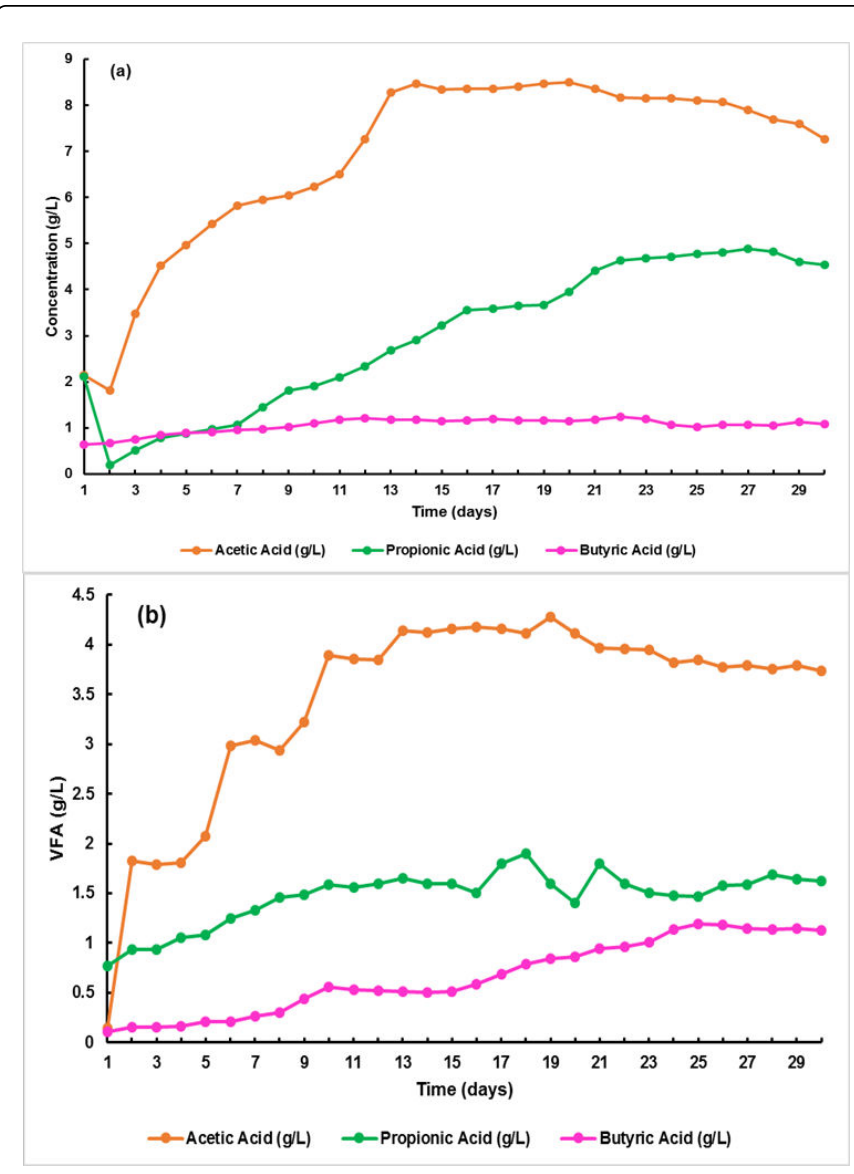

Figure 3: VFA production (g/L) in reactors (a) with methanogenesis and (b) without methanogenesis by addition of $10 \mathrm{mM}$ BES.

\section{Methanogens effect on VFA yield and productivity}

Our studies have shown that, at $\mathrm{pH} 6.5$, in the presence of methanogenesis, cellulose fermentation yielded almost $8 \mathrm{~g} / \mathrm{L}$ of acetic acid and $4.5 \mathrm{~g} / \mathrm{L}$ of propionic acid (Figure 4). Previous studies with crystalline cellulose showed that highest degradation rates occured between $\mathrm{pH} 6.8$ and 7.3 with a $\mathrm{pH}$ close to 6.5 favoring acetic acid production [4]. A similar trend was observed in this study too. At $\mathrm{pH}$ 6.5 , the total VFA produced from cellulose (2.5\% solids loading) was found to be $17.07 \mathrm{~g} / \mathrm{L}$ (acetic acid equivalents). Other studies have also shown similar trends at $\mathrm{pH} 6.5$ [34]. These studies using marine microalgae at $5 \%$ solids loading showed a total VFA production of 15 $\mathrm{g} / \mathrm{L}$, with acetic acid being the predominant VFA produced. Studies have also shown that under thermophilic conditions, acetate yield was $2 \mathrm{mM} / \mathrm{g}$ microcrystalline cellulose added after $60 \mathrm{~h}$ of fermentation. The predominant bacteria found by 454 pyrosequencing, was Clostridium thermocellum and Thermoanaerobacter species [35]. Similar results were found during fermentation of corn stover using rumen bacteria [36]. In a semi-continuous fermentation, they found that total VFA yield was $17 \mathrm{~g} / \mathrm{L}$ with $3 \%$ vs. at $40^{\circ} \mathrm{C}$ during a steady state fermentation. They also found decrease in temperature also decreased VFA production.
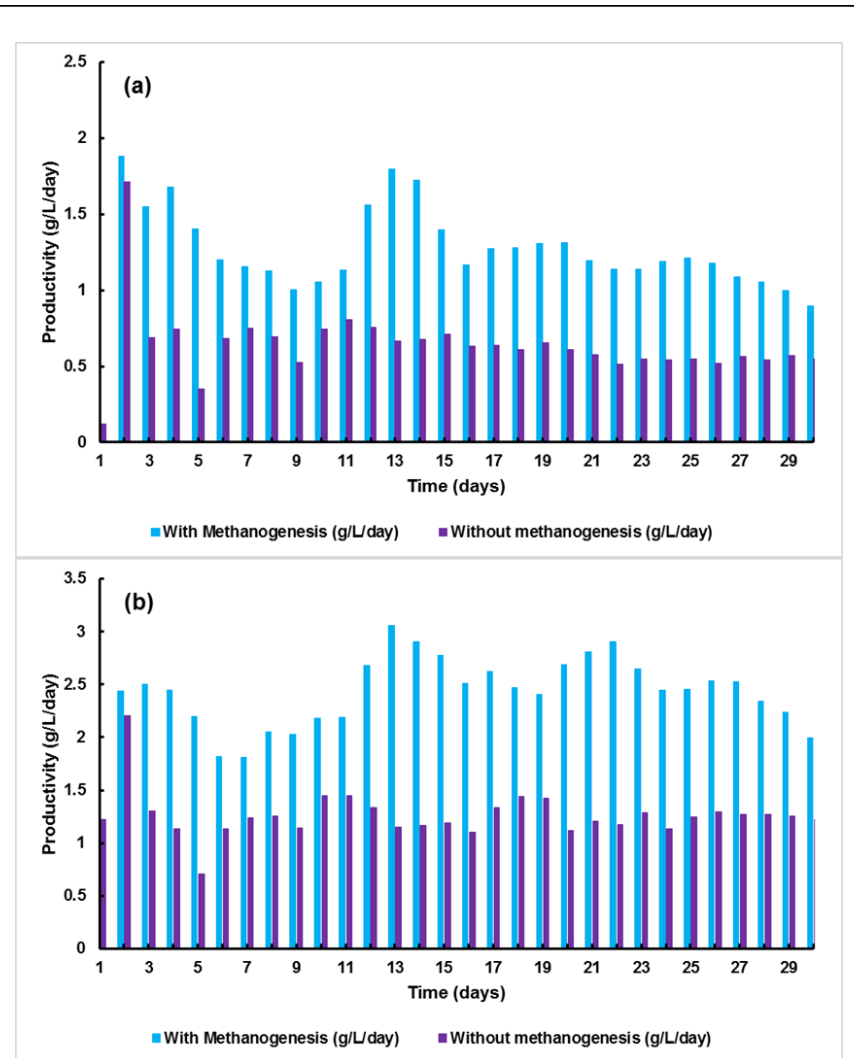

Figure 4: Productivity (g/L/day) in reactors with and without methanogenesis (a) acetic acid productivity and (b) total VFA productivity.

Besides VFA, cellulose degradation under anaerobic conditions produces hydrogen and carbon dioxide. In our study, at $\mathrm{pH} 6.5$, headspace gas analysis revealed a total of $1.9 \%$ hydrogen in the headspace of reactors with methanogenesis along with almost $46 \%$ methane (Table 1), trends that are similar to other research done on anaerobic digestion of sludge $[9,37]$. Studies have also found that between pH 6.0 and $6.5,30 \%$ hydrogen was found in the headspace of anaerobic activated sludge reactors after 8 days of steady state fermentations and acetic, propionic and butyric acids were found to be the predominant acids found in the effluent [38]. Similar trends were observed with acetic acid versus hydrogen concentrations under different $\mathrm{pH}$ conditions. It was found that similar hydrogen concentrations were observed between $\mathrm{pH} 5.5$ and $\mathrm{pH} 6.5$, but at $\mathrm{pH}$ 7.0, hydrogen concentrations decreased and methane concentrations increased.

To selectively inhibit methanogens, $10 \mathrm{mM}$ BES [28] was added on day 1 and again on day 15 to a bioreactor operated in a semicontinuous mode. VFA production decreased from $17 \mathrm{~g} / \mathrm{L}$ with methanogens to $8.3 \mathrm{~g} / \mathrm{L}$ after addition of BES. Changes were also seen in the headspace gases, where the hydrogen concentration significantly increased to $29.2 \%$ from $1.7 \%$ and there was $99.7 \%$ inhibition of methane production after the addition of BES (Table 1). Other studies have found similar results of complete methane inhibition and increase in hydrogen partial pressure, when methanogenesis was inhibited with BES $[28,39]$. Although it is widely understood that BES specifically inhibits methanogens without affecting other microbial populations, 
some studies have found that BES did further inhibit nonmethanogenic cultures as well [39]. Studies have also found that in continuous cultures, where methanogenesis was inhibited $100 \%$, hydrogen production increased from $0.087 \mathrm{mM} /$ day to $1.83 \mathrm{mM} /$ day [21]. A similar observation was made in our study, where hydrogen production increased significantly within 5 days of inhibition of methanogenesis, as discussed in detail in the previous section.

Acetic, propionic and butyric acids were the major acids found in both the reactors. But acetic acid production decreased from $8.5 \mathrm{~g} / \mathrm{L}$ to $4.2 \mathrm{~g} / \mathrm{L}$ after addition of BES. Propionic and butyric acids also showed decreased production after addition of BES. Similar trends were seen with acetic acid productivity and total VFA productivity. Both reactors had similar productivities on days 1 and 2 . However from day 3 , the acetate and total VFA productivity in reactors with methanogenesis was almost twice as high as those in reactors without methanogenesis (Figure 5). The total VFA productivity was $1.8 \mathrm{~g} / \mathrm{L} /$ day with BES compared to $3 \mathrm{~g} / \mathrm{L} /$ day without on day 13 . In the reactor with BES added, the acetate and total VFA productivity remained constant between $0.7-0.8 \mathrm{~g} / \mathrm{L} /$ day and 1.1-1.3 g/L/day, respectively, from day 13 until the end of the experiment (day 30). Other studies have shown similar results where inhibition of methanogenesis results in a decrease in the concentration of acetate and butyrate $[40,41]$. Hence, although methanogenesis was successfully inhibited, it was seen that the BES also affected non-methanogenic bacteria, which probably had a reduced activity as a results of BES.

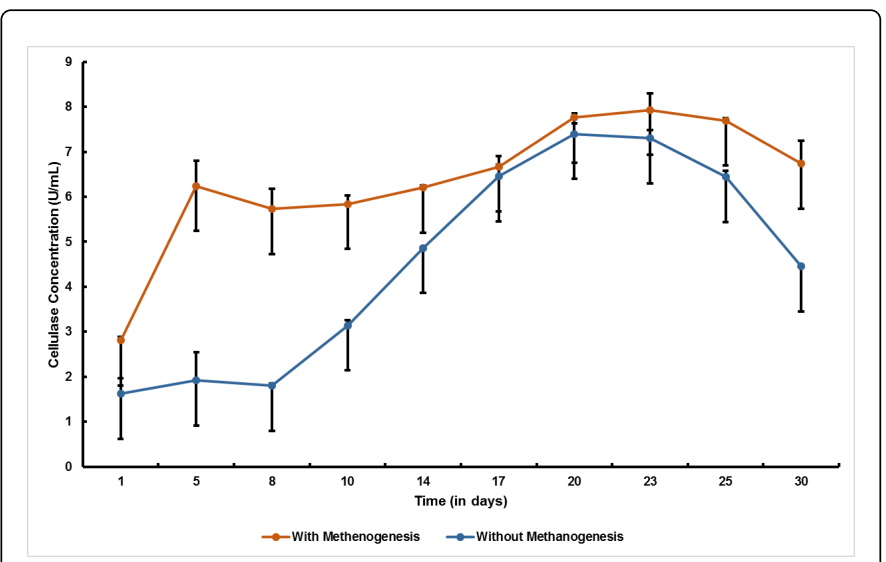

Figure 5: Cellulase concentration $(\mathrm{U} / \mathrm{mL})$ in reactors with and without methanogenesis.

\section{Effect of hydrogen concentrations on acetic acid yield}

It has been well established that cellulose hydrolysis to VFAs further results in production of hydrogen and carbon dioxide. In the rumen, $\mathrm{H}_{2}$ and $\mathrm{CO}_{2}$ is further converted to methane via methanogenesis. This $\mathrm{H}_{2}$ and $\mathrm{CO}_{2}$ are also potentially be used for acetic acid production by specialized homoacetogenic [42]. However, since the methanogens have higher affinity for the $\mathrm{H}_{2}$ and $\mathrm{CO}_{2}$ than the homoacetogens, methanogenesis is favored as the main process by ruminants [20]. In a methanogenesis-inhibited environment, however, increased $\mathrm{H}_{2}$ and $\mathrm{CO}_{2}$ could potentially result in increased acetic acid production, if the necessary microorganism is present in the rumen [20]. In our study it was found that addition of BES resulted in a decrease in VFA production and increase $\mathrm{H}_{2}$ and $\mathrm{CO}_{2}$, which suggest that either the right homoacetogenic populations using $\mathrm{H}_{2}$ and $\mathrm{CO}_{2}$ are not present in the rumen- or that BES is further inhibiting these microorganisms along with other rumen microorganisms. In accordance with this, our studies showed that addition of BES resulted in a decrease in the production of acetic acid from $8.5 \mathrm{~g} / \mathrm{L}$ in reactors without BES to 4.2 $\mathrm{g} / \mathrm{L}$ in reactors with BES. Similar results were found previously, where both the acetic and butyric acid yield decreased after BES addition $[40,41]$.

\section{Dependance of VFA concentration on cellulase activity}

$\beta-1,4-$ endoglucanases catalyze the hydrolysis of cellulose to glucose. The cellulase enzyme complex of Clostridium thermocellum has been widely studied and it was reported that $\beta-1,4-$ endoglucanases hydrolyze the $\beta-1,4$-glucosidic bonds by attacking the cellulose molecule from within [43]. Cellulase activity was measured using Azo-CM Cellulose substrate in samples from reactors with and without methanogenesis, to study the effect of BES on the activity of cellulolytic bacteria in the rumen. It was found that cellulase activity was maximum at day 20 , in both the reactors, where it reached 8 Units/mL. However the cellulase activity in reactor without methanogenesis, was lower than with methanogenesis, on all other days. This data suggests that BES might also affect the cellulolytic population in the rumen. Similar trends were seen by Zhou, et al. in 2011 [44] where qPCR data showed that Fibrobacter succinogens population was inhibited after addition of BES. Fibrobacter succinogens is the major cellulolytic bacteria in cow and sheep rumen, along with Runimococcus albus and Ruminococcus flavifaciens. F. succinogens has an extensive enzymatic system for hydrolysis of cellulose and hemicellulose including glucanases, cellodextrinase, cellobiase and at least six different xylanases [45]. Studies have found that BES significantly inhibits $F$. succinogens, but has little to no effect on $R$. albus and $R$. flavifaciens [43].

\section{Conclusion}

This study is focused on the effect of methanogenesis on VFA production by rumen bacteria utilizing microcrystalline cellulose. Two reactors operated with avicel as substrate and bovine rumen fluid as inoculum. To one of the reactors, $10 \mathrm{mM}$ of 2-bromoethanesulfonate (BES) was added to selectively inhibit the methanogens. It was found that addition of BES decreased the VFA productivity from $3 \mathrm{~g} / \mathrm{L} /$ day, with methanogenesis, to $1.3 \mathrm{~g} / \mathrm{L} /$ day, without methanogenesis and this decrease was believed to be caused by inhibition of several of the rumen microorganisms as a results of BES addition. Previous studies have also found that addition of BES also significantly reduces the acetic acid production $[39,41]$. We further found that inhibition of methanogenesis led to accumulation of hydrogen in the headspace. The hydrogen accumulation was accompanied with a decrease in the acetic acid production indicated that no hydrogen and carbon dioxide utilizing homoacetogenic populations were present in our rumen microflora-or that the ones present were not able to substitute the function of the methanogens. It seems unlikely that this incapability of the homoacetogens to occupy the open niche would be fully due to inhibition by BES-and the constant hydrogen and acetic acid level in reactor without methanogenesis would suggest that these microbes might not be a part of the normal rumen population taking part in the conversion of hydrogen and carbon dioxide in the rumen. While BES inhibition of cellulosic activity has been previously shown, especially related to Fibrobacter succinogens in rumen [43], no previous studies have shown the effect of eliminating methanogenesis on $\mathrm{H}_{2}$ accumulation and VFA yields. 


\section{References}

1. Eichhorn SJ, Young RJ (2001) The Young's modulus of a microcrystalline cellulose. Cellulose 8: 197-207.

2. Battista OA, Smith PA (1962) Microcrystalline cellulose Industrial and Engineering Chemistry. Ind Eng Chem 54: 20-29.

3. Reed PT, Izquierdo JA, Lynd LR (2014) Cellulose fermentation by Clostridium thermocellum and a mixed consortium in an automated repetitive batch reactor. Bioresour Technol 155: 50-56.

4. Hu ZH, Wang G, Yu HQ (2001) Anaerobic degradation of cellulose by rumen microorganisms at various $\mathrm{pH}$ values. Biochem Eng J 21: 59-62.

5. Gijzen HJ, Derikx PL, Vogels GD (1990) Application of rumen microorganisms for a high rate of anaerobic digestions of papermill sludge. Biolog Wast 32: 169-179.

6. Wilson DB (2011) Microbial diversity of cellulose hydrolysis. Curr Opin in Microbiol 14: 259-263.

7. Datta R (1981) Acidogenic fermentation of corn stover. Biotech Bioeng 13: 61-67.

8. Yue ZB, Li WW, Yu HQ (2013) Application of rumen microorganisms for anaerobic bioconversion of lignocellulosic biomass. Bioresour Technol 128: 738-744

9. Ahring BK (2003) Perspectives of Anaerobic Digestion. Adv Biochem Eng Biotechnol 81: 1-30.

10. Wang Y, McAllister TA (2002) Rumen microbes, enzymes and feed digestion A review. Asian Austr J Ani Sci 15: 1659-1676.

11. Miron J, Ben-Ghedalia D, Morrison M (2001) Invited Review Adhesion mechanisms of rumen cellulolytic bacteria. J Dairy Sci 84: 1294-1309.

12. Saleem F, Bouatra S, Guo AC, Psychogios N, Mandal R, et al. (2013) The bovine ruminal fluid metabolome Metabolomic. 6: 360-378.

13. Evans NJ, Brown JM, Murray RD, Getty B, Birtles RJ, et al. (2011) Characterization of novel bovine gastrointestinal tract Treponema isolates and comparison with bovine digital dermatitis treponemes. Appl Environ Microbiol 77: 138-147.

14. Kaoutari AE, Armougom F, Gordon JI, Raoult D, Henrissat B, et al. (2013) The abundance and variety of carbohydrate-active enzymes in the human gut microbiota Nat Rev microbial 11: 497-504.

15. Flint HJ, Martin JC, Thomson AM (2000) Prevotella bryamtii, P. ruminicola and Bacteroides strains. Electrotransform Bact pp: 140-149.

16. Hess M, Sczyrba A, Egan R, Kim TW, Chokhawala H, et al. (2011) Metagenomic Discovery of Biomass-Degrading Genes and Genomes from Cow Rumen. Sci 331: 463-467.

17. Tasse L, Bercovici J, Pizzut-Serin S, Robe P, Tap J, et al. (2010) Functional metagenomics to mine the human gut microbiolome for dietary fiber catabolic enzymes. Genome Res 20: 1605-1612.

18. Danielsson R, Dicksved J, Sun L, Gonda H, Muller B, et al. (2017) Methane production in dairy cows correlates with rumen methanogenic and bacterial community structure. Front Microbiol 8: 1-15.

19. Weimer PJ, Russell JB, Muck RE (2009) Lessons from the cow: what the ruminant animal can teach us about consolidated bioprocessing of cellulosic biomass. Bioresour Technol 100: 5323-5331.

20. McAllister TA, Newbold CJ (2008) Redirecting rumen fermentation to reduce methanogenesis. Austr J Experimental Ahric 48: 7-13.

21. Moraes LE, Strathe AB, Faden JG, Casper DP, Kebreab E, et al. (2014) Prediction of enteric methane emissions from cattle. Global Change Biolo 20: $2140-2148$.

22. Ungerfeld EM (2015) Shifts in metabolic hydrogen sinks in the methanogenesis-inhibited ruminal fermentation: a meta-analysis. Front microbial 6: 37

23. Gagen EJ, Denman SE, McSweeney CS (2015) Acetogenesis as an alternative to methanogenesis in the rumen. Oxfordshire: $\mathrm{CAB}$ International pp: 292-303.

24. Zhang DF, Yang HJ (2012) Combination effects of nitrocompounds, Pyromellitic Diimide and 2-Bromoethanesulfonate on in vitro ruminal methane production and fermentation of a grain-rich feed. J Agric Food Chem 60: 364-371.
25. Liu H, Wang J, Wang A, Chen J (2011) Chemical inhibitors of methanogenesis and putative applications. Appl Microbiol Biotechnol 89: 1333-1340.

26. Chae KJ, Choi MJ, Kim KY, Ajayi FF, Chang IS, et al. (2010) Selective inhibition of methanogens for the improvement of biohydrogen production in microbial electrolysis cells. Internati J Hydro Ener 35: 13379-13386.

27. Kim JR, Min B, Logan BE (2005) Evaluation of procedures to acclimate a microbial fuel cell for electricity production. Appl Microbiol Biotechnol 68: 23-30.

28. Chidthaisong A, Conrad R (2000) Specificity of chloroform, 2bromoethanesulfonate and fluoroacetate to inhibit methanogenesis and other anaerobic processes in anoxic rice field soil. Soil Biolo Biochem 32: 977-988.

29. Murali N, Fernandez S, Ahring BK (2017) Fermentation of wet-exploded corn stover for the production of volatile fatty acids. Bioresour Technol 227: 197-204.

30. Ren NQ, Chua H, Chan SY, Tsang YF, Wang YJ, et al. (2007) Assessing optimal fermentation type for bio-hydrogen production in continuousflow acidogenic reactors. Bioresour technol 98: 1774-1780.

31. Ren N, Wang B, Huang JC (1997) Ethanol-type fermentation from carbohydrate in high rate acidogenic reactor. Biotechnol Bioeng 54: 428-433.

32. Cysneiros D, Banks CJ, Heaven S, Karatzas KAG (2012) The effect of pH control and 'hydraulic flush' om hydrolysis and volatile fatty acids (VFA) production and profile in anaerobic leach bed reactors digesting a high solids content substrate Bioresour Technol 123: 263-271.

33. Zhang L, Chung J, Jiang Q, Sun R, Zhang J, et al. (2017) Characteristics of rumen microorganisms involved in anaerobic degradation of cellulose at various $\mathrm{pH}$ values. RSC Adv 7: 40303-40310.

34. Pham TN, Nam WJ, Jeon YJ, Yoon HH (2012) Volatile fatty acids production from marine algae by anaerobic fermentation. Bioresour Technol 124: 500-503.

35. Carver SM, Nelson MC, Lepisto R, Yu Z, Tuovinen OH, et al. (2012) Hydrogen and volatile fatty acid production during fermentation of cellulosic substrates by thermophilic consortium at 50 and $60^{\circ} \mathrm{C}$. Bioresour Technol 104: 424-431.

36. $\mathrm{Hu} \mathrm{ZH}$, Yu HQ (2005) Application of rumen microorganisms for enhanced anaerobic fermentation of corn stover. Process Biochem 40: 2371-2377.

37. Angelidaki I, Ellegaard L, Ahring BK (2003) Applications of the anaerobic digestion process. Adv Biochem Eng Biotechnol 82: 1-33.

38. Li J, Zheng G, He J, Chang S, Qin Z, et al. (2009) Hydrogen-producing capability of anaerobic activated sludge in three types of fermentations in a continuous stirred-tank reactor. Biotechnol Adv 27: 573-577.

39. Xu KW, Liu H, Chen J (2010) Effect of classic methanogenic inhibitors on the quantity and diversity of archael community and the reductive homoacetogenic activity during the process of anaerobic sludge digestion. Bioresour Technol 101: 2600-2607.

40. Nagaraja TG (1995) Ionophores and antibiotics in ruminants. (In: Wallace RJ, Chesson A) Biotechnology in Animal Feeds and Animal feeding, Weinheim, Germany. pp: 171-204.

41. Baker SK (1999) Rumen methanogens and inhibition of methanogenesis. Aust J Agric Res 50: 1293-1298.

42. Ahring BK, Westermann P (1984) Isolation and characterization of a thermophilic, acetate-utilizing methanogenic bacterium. FEMS Microbiol Lett 25: 47-52.

43. Zverlov VV, Schantz N, Schwarz WH (2005) A major new component in the cellulosome of Clostridium thermocellum is a processive endo- $\beta-1,4-$ glucanase peoducing cellotetraose. FEMS Microbiol Lett 249: 353-358.

44. Zhou Z, Meng Q, Yu Z (2011) Effect of methanogenic inhibitors on methane production and abundances of methanogens and cellulolytic bacteria in In Vitro ruminal cultures. Appl Environ Microbiol 77: 2634-2639. 
Citation: Ahring BK, Murali N, Srinivas K (2018) Fermentation of Cellulose with a Mixed Microbial Rumen Culture with and without Methanogenesis. Ferment Technol 7: 152. doi:10.4172/2167-7972.1000152

Page 7 of 7

45. Bera-Maillet C, Ribot Y, Forano E (2004) Fiber-degrading systems of different strains of the genus Fibrobacter. Appl Environ Microbiol 70: 2172-2179. 